\title{
EFFECTS OF MANAGEMENT OF ICT \\ INFRASTRUCTURAL RESOURCES ON THE IMPLEMENTATION OF TPAD POLICY IN PUBLIC SECONDARY SCHOOLS IN TRANS NZOIA COUNTY, KENYA
}

\author{
Benson Chege Njuguna ${ }^{1 i}$, \\ Lydia Kipkoech', \\ Simon Wanami ${ }^{3}$ \\ ${ }^{1}$ University of Eldoret, \\ Kenya \\ 2,3 Dr., University of Eldoret, \\ Kenya
}

\begin{abstract}
:
This study sought to find out the effect of management of ICT infrastructural resources on the implementation of TPAD Policy in Public Secondary Schools in Trans Nzoia County, Kenya. The study was guided by 'goal-setting theory. Concurrent triangulation design was used to sample 342 Principals and teachers from a target population of 2340 respondents comprising of 242 principals and 2098 teachers from 242 public secondary schools. Stratified and random sampling methods were used to select respondents. Questionnaires were used to collect information and opinions from Principals and teachers. Expert judgments from supervisors were used to improve content validity. Data was analyzed using descriptive and inferential statistics. The results of the study were presented using frequency tables and percentages. From the linear regression model, the study revealed a positive significant effect of teachers' perception on implthe ementation of TPAD policy. From linear regression model, $\left(\mathrm{R}^{2}=.206\right)$ showed that ICT infrastructure resources account for $20.6 \%$ variation in the implementation of TPAD policy. There was a positive significant effect of ICT infrastructure resource $\left(\beta_{3}=0.700\right.$ and $p$ value $\left.<0.05\right)$ on implementation of TPAD policy. Therefore, an increase in ICT infrastructure resources leads to an increase in the implementation of the TPAD policy. The null hypothesis (Ho1) was rejected. ICT infrastructure resoresources a significant influence on the implementation of TPAD policy. This implies that for each increase in the ICT infrastructure resource, there was more implementation of the TPAD policy. The study concluded that the management of teaching staff affects the implementation of TPAD in public secondary schools in Trans Nzoia County. Head teachers with better staff management skills helped teachers to shift to the new paradigm of an appraisal system which has openness, reliability, and accountability as its hallmarks. The Ministry of
\end{abstract}

${ }^{i}$ Correspondence: bensonchege09@gmail.com 
Education and TSC should improve ICT infrastructure especially in sub-county schools and continuously capacity build teachers and school administrators on emerging trends in education management information systems. There is a need for the ministry of education to provide ICT infrastructural resources in every public secondary school in Trans Nzoia County in order to enhance the implementation of TPAD policy.

Keywords: management, ICT, infrastructural, resources, implementation, TPAD policy

\section{Introduction}

Performance Assessment (PA) is an internationally extensive human resources management approach that has also been recognized as a strong motivator (Ademola, 2017). The meaning and the notion of performance assessment have been placed into perspective by many researchers. Bayon (2013) states that performance assessment techniques companies use to assess the performance of their employees in accordance with specific previously set criteria and organizational objectives. Boko, Danku, Dordor, and Solgo (2015) opine that Performance assessment is an ongoing procedure for the determination, measurement, and evaluation of each employee's performance in order to know the areas to be improved. The performance assessment information supplied enhances employee satisfaction, engagement, and motivation.

The integrated Teacher Education and Development Strategic Plan Framework (ISPFTED 2011-2021) was also known as the 'Plan' which integrates teachers' assessment for development via compensation evaluation and wage development. There was no unanimity between the assessment system the implementation of teachers and the government (CDE, 2015). In Uganda, open discussions between managers and staff members are likely to take place during the assessment process. This is occasioned by their highly hierarchical and inflexible administrative culture (Karyeija, 2012). The assessment system was launched in 2016 in Kenya. The objective was to improve public service efficiency and effectiveness (Kamiti, 2014).

Research by Oyaro (2016) on the elements influencing teacher's performance assessment attitudes in Imenti North Sub County public secondary schools indicated that teacher's performance assessment in Kenyan public secondary schools had shortcomings to evaluate. Odhiambo's (2005) teacher assessment study reveals that Kenyan secondary school teachers have experienced shortcomings that need to be addressed by teacher evaluation policies and procedures at Kenyan secondary schools.

The ICT survey findings of England National Statistics (2011) English schools in 2011 were compared with those of 2001, 2008, 2009, and 2010 in comparable surveys. The study outcomes were compared. The results show that between 2008 and 2010, the total of computers per school was steadily intensified, and 2011 had the biggest growth. In addition, internet use, teachers have gradually grown their trust in the use of ICT and expenses for ICT (England National Statistics, 2011). This study was aimed at examining the influence of TPAD on ICT management in schools. The study evaluated how TPAD 
affects different uses and frequency of usage of ICT in school management. Specific focus has been placed on whether there are ICT-dependent learning and teaching activities. The inference here would be that the school management would exhibit a high degree of integration of ICT use.

In Nyamira County, a research was conducted by Ombui (2013) on the problems of integration of ICT to effective administration in high schools. The research conducted a study of the literacy levels of ICT subjects and their problems with respect to hardware and software acquisition. In addition, the study aimed to determine the utilization of ICT. While this study achieved the goals of this study by studying the literacy of the school leaders and the use of information and communication technologies in school administration in part, it is necessary to point out that issues relating to ICT must be assessed.

\section{Statement of the Problem}

Teachers' performance appraisal is integral in the teacher and overall management system. In Kenya, Jonyo \& Jonyo (2017) indicated that the performance assessment procedure did not leave instructors behind. Kanisa and Makokha (2017) corroborated this, stating that until lately was the teacher's performance assessment was a problem. However, although the performance assessment system may enhance the management of secondary schools, its implementation in secondary schools was not without problems.

A research by Menjo \& Boit (2012) about the problems of the use of ICT in Nandi district school administration in Kenya found that ICT was not being properly used by the administration as an administration tool in high schools. It was largely used for clerical functions and in a lesser way for some other administrative tasks, including examination processing. The schools that have contributed to the restricted use of ICT in school administration have discovered that they have encountered great obstacles, including a lack of appropriate training in ICT for teachers and administration lack of time, and absence of appropriate administrative software. This research focuses only on how ICT should be used to administer schools rather than how TPAD should update the usage in schools of ICT-related activities.

He proposes that Principals be educated to allow them to develop the skills needed to effectively utilize ICTs in a related studio by Okeyo (2013) on the Preparedness of the Principals in using information communication technology in public elementary schools in Bondo District, Kenya. Okeyo proposes to incorporate the use of ICT in training. This enables them to utilize and integrate ICT for management objectives. Capable managers relate to people who know how to learn, are innovative, have a high degree of selfefficacy, have new and familiar skills, and work well with others (Okeyo, 2013). It is against this background that this study will be conducted to seek to fill this knowledge gap by determining the establish the effects of management of ICT infrastructural resources on the implementation of TPAD Policy in Public Secondary Schools in Trans Nzoia County. 


\subsection{Objective of the Study}

This study sets out to achieve the following objective:

- To establish the effects of management of ICT infrastructural resources on the implementation of TPAD Policy in Public Secondary Schools in Trans Nzoia County.

\subsection{Research Hypotheses}

Ho1: There is no significant effect of management of ICT infrastructural resources on the implementation of TPAD Policy in Public Secondary Schools in Trans Nzoia County.

\section{Literature}

\subsection{Effects of Management of ICT Infrastructural Resources on Implementation of TPAD Policy}

In this field, the literature focuses mostly on the usefulness of IT in performance assessments. For example, Ahmed (2016)'s performance assessment technology study with specific reference to the HSA group of companies and its Yemeni partners stated that the impact of technology is particularly important on the performance assessment in organisations; it determines whether the organization succeeds or fails in this respect. Technology increases the evaluation process according to them. The research now under progress has tried to look about and see how TPAD has had an influence on the improvement of ICT. This is premised on the fact that the TPAD encourages the use of ICT-related aspects to enhance the teaching and learning process.

Kukulska-Hulme (2012) calls on educators to build mobile learning activities in line with TPAD's understanding of ICT integration. For him, the self-evaluation of teachers might be improved by using mobile devices with records of their classroom performance. Previous researches in Dublin such as Bolona Lopez, Ortiz, and Allen (2015) have shown that cellphones are useful instruments for evaluating the efforts of teaching by student teachers in Ecuador. However, there has been minimal attention to the use of iPads as recording instruments and self-evaluating teachers in geographically distant areas in teaching practice.

Allen, Hadjistassou, and Richardson (2015), who have finished their practical training at Swedish schools, performed a 2015 self-assessment research on iPad teaching among five female teachers in primary education with iPads. The iPad mini was supplied with the pedagogical expectations, the technology training, and resources for five-week trainees in Kenya and Tanzania to enhance contact with instructors and the posting of video from your iPads such as Skype, Adobe Connect, and Moodle. The pre-service teachers saw the usage of iPads as useful means of self-confrontation with teaching records.

A further research was made by Hellrung and Hartig, (2013) in an attempt to address the topic of the relationship between evaluation feedback and teacher performance in Germany in critical assessment of empirical data from several study 
areas. The researchers examined the teacher's opinions and understandings of several elements of feedback, including the intention of their feedback and the effect of their student performance assessments. The researchers established out criteria for choosing the relevant studies and decided on 52 papers that fulfilled their study objectives. The researchers proceeded to group the selected groups according to three thematic areas namely; understanding, purpose, and student performance.

In three areas instructors can utilize ICT, according to Offevenger, van der Akker, and Father (2007): content studies, education and tutoring, and teaching supervised practices. These three categories are key components of efficient programs for education. However, the balance between the three regions should be emphasized as crucial (Offevenger et al., 2007). Leask and Pachler (2013) recommend the implementation of strategies to improve learning and ICT capabilities by the school management. Leask and Pachler (2013) argue that ICT should be seen as a tool of education, learning, and management at this juncture. This has been assisted by ICT defining the vision and task of schools and ensuring that support for ICT is available. Tmison and Taylor (2001) believe that ICT integration asks for reviewing existing ICT activities, new possibilities to use ICT, new tools to explore and enhance new and existing teaching abilities.

\subsection{Theoretical Framework}

The underlying theory of this study is Locke's (1968) goal-setting. Locke's notion of creating objectives says that employees develop goals that encourage them to accomplish greater results (Salaman, Storey \& Billsberry, 2005). The notion of the aim argues that the performance of employees will alter according to the goals of the job. By defining goals, employees are likely to gain from a better concentration on a particular job or aim; more effort; more perseverance in the work; and, in a four-phase process, the encouragement of creativity and innovation.

The first phase involves defining SMART objectives by management (specific, measurable, feasible, realistic, and time-based). The management motivates employees to participate in the second stage in defining goals and in achieving their own objectives. During the third phase, the management gives workers with suitable assistance and resources to fulfill their goals. Finally, the management gives timely feedback on employee performance evaluation in the fourth step.

The theory is utilized in TPAD because it includes five main phases: performance standards establishments, performance communications, actual performance measurement, the comparison of current and expected results, and, when necessary, corrective action initiations (Surbhi, 2015). The notion of targeting stresses that employees can change their goals in accordance with their performance. If employees understand the performance assessment framework well, they are likely to participate productively in the assessment process which improves their professional growth and learning results to the student.

The performance assessments can identify the contribution of instructors to student learning outcomes. Performance evaluation begins with the creation of 
performance standards followed by communication of performance expectations, measuring actual performance, and comparison of actual performance with expected performance (Surbhi, 2015). The performance assessment covers four phases of Locke's idea of creating goals, namely, objectives; the enlistment of employee approval and involvement; suitable assistance and resources; and, finally, timely feedback from employee performance assessments (Locke \& Latham, 2002).

In addition, the TPAD framework fails to establish whether teacher experience with respect to the number of years spent in teaching or the extra skills gained during the educational system significantly contributes to student learning accomplishment. Under the TPAD framework, experience is not a component of teacher performance. Consequently, the performance assessment will probably demotivate experienced instructors who are unable to value the results of the process in keeping with the 'valence' of the expectations theory of Vrooms. Contrary to Locke's goal-setting theory it is thus necessary to analyze the performance targets established by the more experienced teachers.

\section{Research Methodology}

This study was based on a pragmatic philosophical research paradigm whose approach applies pluralistic means of acquiring knowledge about a phenomenon (Morgan, 2007). Creswell (2013) supports this and argues that, ragmatism makes it possible to work within the positivist and interpretivist approaches. Pragmatism is generally regarded as the philosophical partner for the mixed methods approach. Pragmatic research philosophy is suitable for this study because it allowed the researcher to use whatever combination of methods necessary to find answers to research questions. According to Mertens (2007), a mixed-method is one in which both quantitative and qualitative methods are used to answer research questions in a single study or a multiphase study. The study adopted a descriptive survey research design. This design was appropriate because it gives conclusive results among the research variables.

The study was carried out in Trans-Nzoia County. The county has an area of $2,469.9 \mathrm{~km}^{2}$ and is divided into five administrative sub-counties namely; Trans Nzoia west/Saboti, Trans Nzoia East, Kiminini, Endebes, and Kwanza. The population of the county was 818,585 . The secondary school age cohort is 104,473 with 69,998 enrolled (CDE's office, Trans Nzoia County). Trans Nzoia is a county with a rich socio-economic endowment basically hinged on maize production and other agricultural activities. There is also notable variation in how schools perform KCSE.

The target population was all secondary school teachers in Trans-Nzoia County, while the target population consists of the 242 public secondary schools in Trans-Nzoia County. The target population was 2340 respondents comprising of 242 principals and 2098 teachers from 242 public secondary schools. The sample size was drawn from 2340 respondents comprising of 242 principals and 2098 teachers from 242 public secondary schools in Trans-Nzoia County. Yamane (1967) provides a simplified formula for 
calculating the sample size of the respondents. From the target population of 2340 respondents, the researcher used proportionate sampling to select 342 respondents.

The study applied stratified sampling to create strata comprising of five Sub counties. The strata ensured representation of subjects by school type in the sample. Purposive sampling was used to select principals in national and extra county schools in the sample. Principals were selected using stratified random sampling after establishing the number of schools per category in each sub-county. Teachers sampled through proportionate simple random sampling to ensure representation in the sample of teachers from different school strata. The sampling technique gave employees in the population an equal probability of being in the sample

The study used both primary and secondary data using questionnaires, interviews, and document analysis. The study used a questionnaire to collect primary data from respondents. The questionnaire contained close-ended questions based on study objectives. The questionnaire employed the five-point Likert scale where 1 represents Strongly Disagree 2 represents Disagree 3 represents Neutral 4 represents Agree and 5 represents Strongly Agreed. Principals were guided through a scheduled interview in order to get an in-depth opinion about the use of TPAD in their schools.

The collected data was analysed using descriptive and inferential statistics with the help of a statistical package for social sciences (SPSS). Data collected from the field were cleaned, coded, and analyzed using descriptive statistics and Statistical Package for Social Sciences (SPSS V. 26). Results were presented in the form of frequency and percentages. Correlation analysis were done to determine the relationship between variables.

\section{Results}

\subsection{Effects of Management of ICT Infrastructural Resources on Implementation of TPAD Policy in Public Secondary Schools in Trans Nzoia County}

The objective was to establish the effects of management of ICT infrastructural resources on the implementation of TPAD Policy in Public Secondary schools in Trans Nzoia County. This objective was analyzed using descriptive statistics (frequency, percent, mean, and standard deviation) and inferential statistics (Pearson product-moment correlation analysis and linear regression).

\subsection{Implementation of Teacher Performance Appraisal and Development}

The respondents were asked to rate on a five-point Likert scale their level of agreement on several statements describing the implementation of Teacher Performance Appraisal and Development (TPAD) in terms of target settings, feedback, and reward system in Public Secondary schools in Trans Nzoia County and their response were summarized in the following sections. 


\subsection{Target Setting}

The respondents were asked to rate target settings in the implementation of TPAD. The findings are indicated in Table 1. Findings indicated that $112(37.5 \%)$ of the respondents strongly disagreed that there was a pre-appraisal conference involving all staff to set performance targets, 125 (41.7\%) indicated disagreed, 30 (10\%) agreed while 20 (6.7\%) strongly agreed. The obtained Mean $=2.07, \mathrm{SD}=1.190$ shows that majority of the respondents disagreed that there was a pre-appraisal conference involving all staff to set performance targets. It is important to note that this is the initial stage of the TPAD and therefore if the majority of the schools did not have the conference then the target setting which is essential in the TPAD implementation will be likely be impacted.

Though the findings indicated that the pre-appraisal conference was not held in many of the schools Alubbe (2015) was of the opinion that performance appraisal in secondary schools is a yearly event where performance evaluation forms are supposed to be filled. However, the author notes that this is normally done in a hasty manner that doesn't befit the appraisal process. The author agrees with findings that indicated that a few schools were participating in the pre-appraisal conference affirming that the most important conditions of performance appraisal such as identifying performance gaps, giving feedback to teachers that lead to effective appraisals are ignored.

Findings in Table 1 indicated that $32(10.7 \%)$ of the respondents strongly disagreed that teachers set goals at the beginning of every appraisal period (term), 43 (14.3\%) indicated disagreed, 125 (41.7\%) strongly agreed while 95 (31.7\%) agreed. The obtained Mean 3.793, SD $=1.389$ shows that majority of the respondents agreed that teachers set goals at the beginning of every appraisal period. Though pre-conference was not highly rated in schools apparently teachers were involved in setting targets at the beginning of the term thereby giving the action plan that schools need to take and achieve. This is in line with Locke and Latham (2007), who opined that target or goal setting and reflection have been found to have a powerful impact on action. This is a fact that is reaffirmed by Timperley, (2011) who insists that target setting is central to the development of selfregulated learning, capacity, and this assists teacher to identify what they need to do to improve their practices and to know what is expected of them.

Table 1: Implementation of TPAD Target Settings

\begin{tabular}{|l|c|c|c|c|c|c|c|}
\hline Target setting & SD & D & N & A & SA & Mean & SD \\
\hline $\begin{array}{l}\text { a. } \\
\begin{array}{l}\text { There is a pre- } \\
\text { appraisal conference } \\
\text { involving all staff to } \\
\text { set performance } \\
\text { targets }\end{array}\end{array}$ & $\begin{array}{c}112 \\
(37.3 \%\end{array}$ & $\begin{array}{c}125 \\
(41.7 \%)\end{array}$ & $\begin{array}{c}13 \\
(4.3 \%)\end{array}$ & $\begin{array}{c}30 \\
(10 \%)\end{array}$ & $\begin{array}{c}20 \\
(6.7 \%)\end{array}$ & 2.070 & 1.190 \\
\hline $\begin{array}{l}\text { b. } \\
\begin{array}{l}\text { Teachers set goals at } \\
\text { the beginning of } \\
\text { every appraisal } \\
\text { period (term) }\end{array}\end{array}$ & $\begin{array}{c}32 \\
(10.7 \%)\end{array}$ & $\begin{array}{c}43 \\
(14.3 \%)\end{array}$ & $\begin{array}{c}5 \\
(1.7 \%)\end{array}$ & $\begin{array}{c}95 \\
(31.7 \%)\end{array}$ & $\begin{array}{c}125 \\
(41.7 \%\end{array}$ & 3.793 & 1.389 \\
\hline c. $\begin{array}{l}\text { There is a shared } \\
\text { understanding of the }\end{array}$ & $\begin{array}{c}95 \\
(31.7 \%\end{array}$ & $\begin{array}{c}131 \\
(43.7 \%)\end{array}$ & $\begin{array}{c}12 \\
(4 \%)\end{array}$ & $\begin{array}{c}41 \\
(13.7 \%)\end{array}$ & $\begin{array}{c}21 \\
(7 \%)\end{array}$ & 2.207 & 1.223 \\
\hline
\end{tabular}




\begin{tabular}{|c|c|c|c|c|c|c|c|c|}
\hline & $\begin{array}{l}\text { various performance } \\
\text { competency areas in } \\
\text { the TPAD and what } \\
\text { they entail }\end{array}$ & & & & & & & \\
\hline d. & $\begin{array}{l}\text { There is deliberate } \\
\text { effort to understand } \\
\text { the performance } \\
\text { target and what to do } \\
\text { to meet the targets }\end{array}$ & $\begin{array}{c}47 \\
(15.7 \%)\end{array}$ & $\begin{array}{c}55 \\
(18.3 \%)\end{array}$ & $\begin{array}{c}15 \\
(55)\end{array}$ & $\begin{array}{c}97 \\
(32.3 \%)\end{array}$ & $\begin{array}{c}86 \\
(28.7 \%)\end{array}$ & 3.400 & 1.458 \\
\hline e. & $\begin{array}{l}\text { My superiors } \\
\text { regularly discuss my } \\
\text { goals with me }\end{array}$ & $\begin{array}{c}28 \\
(9.3 \%)\end{array}$ & $\begin{array}{c}25 \\
(8.3 \%)\end{array}$ & $\begin{array}{c}6 \\
(2 \%)\end{array}$ & $\begin{array}{c}99 \\
(33 \%)\end{array}$ & $\begin{array}{c}142 \\
(47.3 \%)\end{array}$ & 4.007 & 1.293 \\
\hline f. & $\begin{array}{l}\text { Deadlines are set as } \\
\text { per the school } \\
\text { calendar of activities }\end{array}$ & $\begin{array}{c}33 \\
(11 \%)\end{array}$ & $\begin{array}{c}30 \\
(10 \%)\end{array}$ & $\begin{array}{c}3 \\
(1 \%)\end{array}$ & $\begin{array}{c}100 \\
(33.3 \%)\end{array}$ & $\begin{array}{c}134 \\
(44.7 \%)\end{array}$ & 3.907 & 1.358 \\
\hline g. & $\begin{array}{l}\text { Right tools are } \\
\text { provided to achieve } \\
\text { target }\end{array}$ & $\begin{array}{c}49 \\
(16.3 \%)\end{array}$ & $\begin{array}{c}44 \\
(14.7 \%)\end{array}$ & $\begin{array}{c}4 \\
(1.3 \%)\end{array}$ & $\begin{array}{c}100 \\
(33.3 \%)\end{array}$ & $\begin{array}{c}103 \\
(34.3 \%)\end{array}$ & 3.547 & 1.488 \\
\hline h. & $\begin{array}{l}\text { Appraisee and } \\
\text { appraiser discuss } \\
\text { observation, } \\
\text { assessment and agree } \\
\text { on the targets }\end{array}$ & $\begin{array}{c}99 \\
(33 \%)\end{array}$ & $\begin{array}{c}130 \\
(43.3 \%)\end{array}$ & $\begin{array}{c}12 \\
(4 \%)\end{array}$ & $\begin{array}{c}39 \\
(13 \%)\end{array}$ & $\begin{array}{c}20 \\
(6.7 \%)\end{array}$ & 2.170 & 1.211 \\
\hline i. & $\begin{array}{l}\text { Teachers } \\
\text { performance for the } \\
\text { term is evaluated } \\
\text { against the } \\
\text { competency areas } \\
\text { and appraisal rating } \\
\text { for the term agreed } \\
\text { upon }\end{array}$ & $\begin{array}{c}42 \\
(14 \%)\end{array}$ & $\begin{array}{c}13 \\
(4.3 \%)\end{array}$ & $\begin{array}{c}20 \\
(6.7 \%)\end{array}$ & $\begin{array}{c}124 \\
(41.3 \%)\end{array}$ & $\begin{array}{c}101 \\
(33.7 \%)\end{array}$ & 3.763 & 1.337 \\
\hline j. & $\begin{array}{l}\text { Targets are set } \\
\text { objectively }\end{array}$ & $\begin{array}{c}85 \\
(28.3 \% \\
\end{array}$ & $\begin{array}{c}140 \\
(46.7 \%) \\
\end{array}$ & $\begin{array}{c}5 \\
(1.7 \%) \\
\end{array}$ & $\begin{array}{c}44 \\
(14.75) \\
\end{array}$ & $\begin{array}{c}26 \\
(8.7 \%) \\
\end{array}$ & 2.287 & 1.261 \\
\hline
\end{tabular}

Findings in Table 1 indicated that 95 (31.7\%) of the respondents strongly disagreed that there is a shared understanding of the various performance competency areas in the TPAD and what they entail 131 (43.7\%) indicated disagreed, 41 (13.7\%) greed while 21 (7\%) agreed. Findings indicated that the majority of the respondents disagreed that there is a shared understanding of the various performance competency areas in the TPAD and what they entail (Mean $=2.207, \mathrm{SD}=1.223$ ). This implies that target ratings from the appraiser and appraisee in the various areas such as time management may not be in harmony given the misunderstanding.

Findings in Table 1 indicated that 47 (15.7) of the respondents strongly disagreed that there is deliberate effort to understand the performance target and what to do to meet the targets 55 (18.3\%) indicated disagreed, $97(32.3 \%)$ agreed while $86(28.7 \%)$ agreed. Findings indicated that the majority of the respondents agreed (Mean $=3.4, \mathrm{SD}=$ 1.458) that there is a deliberate effort to understand the performance target and what to 
do to meet the targets. This implies that the appraisers who include the Principal, Deputy Principal, and Heads of Department conduct formal and informal meetings in order to see the progress and do the continuous ratings. This finding is consistent with Alubbe (2015) who contended that during the assessment and review phase, strengths, weaknesses, success, and areas needing improvement are identified. The performance appraisal system should focus on the strengths and accomplishments of staff, rather than their faults and failures. It should in turn lead to a plan for future development and progress of the individual.

Findings in Table 1 indicated that $28(9.3 \%)$ of the respondents strongly disagreed that superiors regularly discuss goals with teachers, 25 (8.3\%) indicated disagreed, 99 $(33 \%)$ agreed while $142(47.3 \%)$ agreed. Findings indicated tha the majority of the respondents agreed (Mean $=4.007, \mathrm{SD}=1.293$ ) that superiors regularly discuss goals with teachers. This implies that the appraisers who include the Principal, Deputy Principal, and Heads of Department were able to meet with teachers to verify evidences related to the target settings.

In line with this finding is Kamuri (2012) assertion that P.A should be done in an environment where the teacher and the employer work together to determine measures for evaluating each of the objectives. On the same note, this strengthens the trust and the relationship between the two thus enhancing the teacher's motivation. During the appraisal process, every teacher must be actively involved and be informed throughout the process. Teachers' involvement in the P.A process makes them own the process and be part of it, therefore, re-enhancing their intrinsic motivation that is to result in improved performance. If the aspects for performance appraisal are not available then the teacher is likely to be demotivated.

Further findings in Table 1 indicated that 33 (11\%) of the respondents strongly disagreed that deadlines are set as per the school calendar of activities, 30 (10\%) indicated disagreed, 100 (33.3\%) agreed while 134 (44.7\%) agreed. Findings indicated that the majority of the respondents agreed (Mean $=3.907, \mathrm{SD}=1.358)$ that deadlines are set as per the school calendar of activities. This implies that marking of examination, submitting of schemes of work, records, and presentation of marks among other activities in the school were being done alongside the time that has been set aside.

Further findings in Table 1 indicated that 49 (16.3\%) of the respondents strongly disagreed that the right tools are provided to achieve targets, $44(14.7 \%)$ indicated disagreed, 100 (33.3\%) agreed while 103 (34.3\%) agreed. Findings indicated that the majority of the respondents agreed (Mean $=3.547, \mathrm{SD}=1.488$ ) that the right tools are provided to achieve targets. This implies that teachers were provided with teaching and learning resources such as textbooks, teaching aids, and physical resources such as libraries, classes, and laboratories to carry out their work effectively. These findings are similar to Stronge and Tuckers (2003) who contend that teachers have confidence in the performance appraisal evaluation and that the involvement of multiple evaluators and sources of evidence is essential to appraisal systems credibility. 
In relation to their findings, it is clear that a lot and diverse range of evaluations and right tools are required so as to ensure the effectiveness of performance appraisal and to determine its credibility and its motivational consequences on the teachers. Even if there is evidence from researchers that teachers have confidence in the performance appraisal, other researchers have also found out that the process of performance appraisal evaluation does not motivate teachers. Darling Hammond (2013) asserts that teacher evaluation and appraisal systems do little to help teachers improve. This may indicate that performance appraisal evaluation does not influence teacher motivation so as to enhance the quality of teaching or lead to long-lasting change (Kamener, 2012). It is due to these contradicting findings that the current study seeks to establish perceptions regarding the effects of TPAD.

Further findings in Table 1 indicated that 99 (33\%) of the respondents strongly disagreed that the appraisee and appraiser discuss observation, assessment and, agree on the targets, 130 (43.3\%) indicated disagreed, 39 (13\%) agreed while 20 (6.7\%) agreed. Findings indicated that the majority of the respondents disagreed (Mean $=2.170, \mathrm{SD}=$ 1.211) that the appraisee and appraiser discuss observation, assessment and agree on the targets. This implies that lessons observation may be a challenge in school in terms of TPAD implementation. The TPAD stipulates that teachers be observed at least once in a term. Because of the personal reasons that teachers give these observations are hardly carried out. This explains the low ratings envisaged in this statement regarding target settings.

Further findings in Table 1 indicated that 42 (14\%) of the respondents strongly disagreed that teacher's performance for the term is evaluated against the competency areas and appraisal rating for the term agreed upon, 13 (4.3\%) indicated disagreed, 124 $(41.3 \%)$ agreed while $101(33.7 \%)$ agreed. Findings indicated that the majority of the respondents agreed (Mean $=3.763, \mathrm{SD}=1.337$ ) that teachers' performance for the term is evaluated against the competency areas and appraisal rating for the term agreed upon. This implies that TPAD was objective and not just arbitrary in which targets are subjectively awarded. However, in education, it is difficult to assess the processes of teaching and learning by outcome alone.

Mbatha (2017) indicates that the complex nature of classroom processes and the subtle interaction of teaching and learning are not easy to measure. It can be argued that emphasis on outcome alone, as in industry and commerce, would mean that the assessment concentrates on pupils only without taking cognizance of the teacher's influence. Lastly, findings in Table 1 indicated that $85(28.3 \%)$ of the respondents strongly disagreed that targets are set objectively, 140 (46.7\%) indicated disagreed, 44 (14.7\%) agreed while $26(8.7 \%)$ agreed. Findings indicated that the majority of the respondents disagreed $($ Mean $=2.287, \mathrm{SD}=1.261)$ that targets are set objectively. This implies that there is a possibility of teachers putting targets that were not realistic. This means that they may not be able to achieve the targets at the end of the term or even the end of the term.

In a related study by Tshabalala and Mapolisa (2013) on the problems faced by heads of schools and teachers in the implementation of performance appraisal in Nkayi 
District, Zimbabwe, issues related to arbitrary target setting were mentioned. The key findings were that; though at the beginning of the appraisal period the appraisee formulated the objectives of the period with the assistance of the supervisor, the teacher's role was passive in setting up their production targets and self-evaluation on their achievements. Formulation of objectives, target setting, a standard form, rating by head teachers, and self-evaluation as the methods of appraising teachers in primary and high school.

\subsection{Feedback}

The respondents were asked to rate on feedback in the implementation of TPAD. The findings are indicated in Table 2. Findings indicated that $113(37.7 \%)$ of the respondents strongly disagreed that teachers get adequate feedback on their performance based on performance appraisal form, 107 (35.7\%) indicated disagreed, 35 (11.7\%) agreed while 25 $(8.3 \%)$ strongly agreed. The obtained Mean $2.173, \mathrm{SD}=1.279$ shows that majority of the respondents disagreed that teachers get adequate feedback on their performance based on the performance appraisal form. It is important to note that feedback is important in the TPAD process of implementation.

Through feedback, teachers will be able to know their progress in the targets that they had set. A possible explanation for this may be that either the appraisee or appraiser was taking a lot of time in submitting the TPAD for rating thus the inadequacy of providing feedback. Consistent with this finding is Higgins and McCann's (1984) assertion that managers who deliver negative feedback to an employee also tend to develop a less than favorable impression of that person, and vice versa with the effect becoming stronger over time.

Table 2: Implementation of TPAD Policy Feedback

\begin{tabular}{|c|c|c|c|c|c|c|c|}
\hline Feedback & SD & D & $\mathbf{N}$ & A & SA & Mean & Std. Dev \\
\hline $\begin{array}{l}\text { a. Teachers get } \\
\text { adequate feedback on } \\
\text { their performance } \\
\text { based on } \\
\text { performance } \\
\text { appraisal form }\end{array}$ & $\begin{array}{c}113 \\
(37.7 \%\end{array}$ & $\begin{array}{c}107 \\
(35.7 \%)\end{array}$ & $\begin{array}{c}20 \\
(6.7 \%)\end{array}$ & $\begin{array}{c}35 \\
(11.7 \%)\end{array}$ & $\begin{array}{c}25 \\
(8.3 \%)\end{array}$ & 2.173 & 1.279 \\
\hline $\begin{array}{ll}\text { b. } & \text { Teachers always get } \\
\text { performance } \\
\text { feedback on time }\end{array}$ & $\begin{array}{c}117 \\
(39 \%)\end{array}$ & $\begin{array}{c}96 \\
(32 \%)\end{array}$ & $\begin{array}{c}3 \\
(1 \%)\end{array}$ & $\begin{array}{c}42 \\
(14 \%)\end{array}$ & $\begin{array}{c}42 \\
(14 \%)\end{array}$ & 2.320 & 1.458 \\
\hline $\begin{array}{ll}\text { c. } & \text { Supervisors discusses } \\
& \text { with teachers work } \\
\text { performance during } \\
\text { appraisal sessions }\end{array}$ & $\begin{array}{c}97 \\
(32.3 \%)\end{array}$ & $\begin{array}{c}127 \\
(42.3 \%)\end{array}$ & $\begin{array}{c}4 \\
(1.3 \%)\end{array}$ & $\begin{array}{c}23 \\
(7.7 \%)\end{array}$ & $\begin{array}{c}49 \\
(16.3 \%)\end{array}$ & 2.333 & 1.417 \\
\hline $\begin{array}{l}\text { d. } \\
\text { received agrees with } \\
\text { what teachers have } \\
\text { actually achieved } \\
\end{array}$ & $\begin{array}{c}39 \\
(13 \%)\end{array}$ & $\begin{array}{c}50 \\
(16.7 \%)\end{array}$ & $\begin{array}{c}15 \\
(5 \%)\end{array}$ & $\begin{array}{c}103 \\
(34.3 \%)\end{array}$ & $\begin{array}{c}93 \\
(31 \%)\end{array}$ & 3.537 & 1.410 \\
\hline
\end{tabular}




\begin{tabular}{|c|c|c|c|c|c|c|c|c|}
\hline e. & $\begin{array}{l}\text { Supervisors } \\
\text { communicates with } \\
\text { teachers frequently } \\
\text { on their work } \\
\text { performance }\end{array}$ & $\begin{array}{c}104 \\
(34.7)\end{array}$ & $\begin{array}{c}124 \\
(41.3 \%)\end{array}$ & $\begin{array}{c}14 \\
(4.7 \%)\end{array}$ & $\begin{array}{c}31 \\
(10.3 \%)\end{array}$ & $\begin{array}{c}27 \\
(9 \%)\end{array}$ & 2.177 & 1.261 \\
\hline f. & $\begin{array}{l}\text { The performance } \\
\text { feedback teachers } \\
\text { receive is highly } \\
\text { appreciated }\end{array}$ & $\begin{array}{c}41 \\
(13.7 \%)\end{array}$ & $\begin{array}{c}34 \\
(11.3 \%)\end{array}$ & $\begin{array}{c}13 \\
(4.3 \%)\end{array}$ & $\begin{array}{c}117 \\
(39 \%)\end{array}$ & $\begin{array}{c}95 \\
(31.7 \%)\end{array}$ & 3.637 & 1.385 \\
\hline g. & $\begin{array}{l}\text { Teachers receive only } \\
\text { verbal feedback from } \\
\text { their supervisor }\end{array}$ & $\begin{array}{c}144 \\
(48 \%)\end{array}$ & $\begin{array}{c}125 \\
(41.7 \%)\end{array}$ & $\begin{array}{c}18 \\
(6 \%)\end{array}$ & $\begin{array}{c}8 \\
(2.7 \%\end{array}$ & $\begin{array}{c}5 \\
(1.7 \%)\end{array}$ & 1.683 & 0.836 \\
\hline h. & $\begin{array}{l}\text { Teachers receive both } \\
\text { verbal and written } \\
\text { feedback from their } \\
\text { supervisor }\end{array}$ & $\begin{array}{c}20 \\
(6.7 \%)\end{array}$ & $\begin{array}{c}25 \\
(8.3 \%)\end{array}$ & $\begin{array}{c}11 \\
(3.7 \%)\end{array}$ & $\begin{array}{c}104 \\
(34.7 \%)\end{array}$ & $\begin{array}{c}140 \\
(46.7 \%)\end{array}$ & 4.063 & 1.199 \\
\hline i. & $\begin{array}{l}\text { My supervisors holds } \\
\text { a performance review } \\
\text { meeting to discuss } \\
\text { my performance } \\
\text { outcome }\end{array}$ & $\begin{array}{c}42 \\
(14 \%)\end{array}$ & $\begin{array}{c}15 \\
(5 \%)\end{array}$ & $\begin{array}{c}21 \\
(7 \%)\end{array}$ & $\begin{array}{c}124 \\
(41.3 \%)\end{array}$ & $\begin{array}{c}98 \\
(32.7 \%)\end{array}$ & 3.737 & 1.339 \\
\hline $\mathrm{j}$. & $\begin{array}{l}\text { I am provided with } \\
\text { feedback based on } \\
\text { factual evidence on } \\
\text { my performance }\end{array}$ & $\begin{array}{c}33 \\
(11 \%)\end{array}$ & $\begin{array}{c}41 \\
(13.7 \%)\end{array}$ & $\begin{array}{c}7 \\
(2.3 \%)\end{array}$ & $\begin{array}{c}113 \\
(37.7 \%)\end{array}$ & $\begin{array}{c}106 \\
(35.3 \%)\end{array}$ & 3.727 & 1.358 \\
\hline
\end{tabular}

Findings in Table 2 indicated that 117 (39\%) of the respondents strongly disagreed that teachers always get performance feedback on time, 96 (32\%) indicated disagreed, 42 $(14 \%)$ agreed while $42(14 \%)$ strongly agreed. The findings obtained show that the majority of the respondents disagreed that teachers always get performance feedback on time (Mean 2.320, SD = 1.458). Hattie, Gan and \& Brooks (2011) contend that quick feedback through one-minute goals, one-minute recognition, and one-minute re-directs highly contributes to the accomplishment of organizations. Through enabling workers to acquire better information about how well they performed, what they should improve, and how their supervisor feels about it; employees feel better about themselves and, in this manner, they produce better outcomes. This is in line with the current study which feels that it is imperative for quick feedback to be given in order for the appraisee to know where to improve.

Findings in Table 2 indicated that 97 (32.3\%) of the respondents strongly disagreed that supervisors discuss with teachers work performance during appraisal sessions, 127 $(42.3 \%)$ indicated disagreed, $23(7.7 \%)$ agreed while $49(16.3 \%)$ strongly agreed. The findings obtained show that the majority of the respondents disagreed that supervisors discuss with teachers work performance during appraisal sessions (Mean $=2.333, \mathrm{SD}=$ 1.417). This finding indicates that possibly ratings were done independently without a meeting or sessions with the two parties involved. This may result into wrong ratings that may impact on the implementation of the TPAD. However, it is important to mention 
that a few supervisors were able to meet with teachers in order to discuss with teachers their performance.

Critically important is that involving all actors in the process of appraisal is useful in attaining the goals of the organization. Literature indicates that teachers who are involved in developing the appraisal system are more likely to be aware and accept performance expectations, understand better the appraisal process and outcome, and are committed to the appraisal system (Kelly et al., 2008). This is a fact that has been refuted by (Schultz and Schultz 2010) who asserts that performance appraisals have no positive rating from the employees and that they should not participate in them.

Findings in Table 2 indicated that 39 (13\%) of the respondents strongly disagreed that the feedback received agrees with what teachers have actually achieved, 50 (16.7\%) indicated disagreed, 103 (34.37\%) agreed while 93 (31\%) strongly agreed. The findings obtained showshowt the majority of the respondents agreed that the feedback received agrees with what teachers have actually achieved (Mean $=3.537, \mathrm{SD}=1.41$ ). This finding indicates that teachers were meeting the targets they had earlier on set. Targets such as learners' progress may be met that is why there was consensus in the scores given.

This finding is contrary to what Brown, Kulik, and Lim (2016) asserted that managers typically avoid giving negative feedback to poor performers. Therefore, poor performers are often not given the feedback that they need in order to succeed in their roles. Though contradicting sentiments have been raised, it is useful to point out that there was indeed feedback. The current study attempted to fill this gap by looking at the perceptions of appraisees in the processes and procedures involved during the appraisal process.

Findings in Table 2 indicated that 104 (34.7\%) of the respondents strongly disagreed that the supervisors communicate with teachers frequently on their work performance, 124 (41.3\%) indicated disagreed, 31 (10.3\%) agreed while 27 (9\%) strongly agreed. The findings obtained show that the majority of the respondents disagreed that supervisors communicate with teachers frequently on their work performance (Mean = 2.117, $\mathrm{SD}=1.261$ ). This finding indicates that supervisors may not be meeting with teachers to communicate on the progress of the TPAD targets that had been set. There may be weak channels of communication that might have necessitated low communication.

Findings in Table 2 indicated that $41(13.7 \%)$ of the respondents strongly disagreed that the performance feedback teachers receive is highly appreciated, $34(11.3 \%)$ indicated disagreed, 117 (39\%) agreed while 95 (31.7\%) strongly agreed. The findings obtained show that majority of the respondents agreed that the performance feedback teachers receive is highly appreciated (Mean $=3.637, \mathrm{SD}=1.385$ ). This finding implies that teachers were probably doing much that deserves to be appreciated.

Findings in Table 2 indicated that 144 (48\%) of the respondents strongly disagreed that teachers receive only verbal feedback from their supervisor, 125 (41.7\%) disagreed, $8(2.7 \%)$ agreed while $5(1.7 \%)$ strongly agreed. The findings obtained show that the majority of the respondents disagreed teachers receive only verbal feedback from their 
supervisor $($ Mean $=1.683, \mathrm{SD}=0.836$ ). This finding indicates that the supervisors were using formal feedback such as approving records of work and progress records.

Findings in Table 2 indicated that $20(6.7 \%)$ of the respondents strongly disagreed that teachers receive both verbal and written feedback from their supervisor, 25 (8.3\%) disagreed, 104 (34.7\%) agreed while 140 (46.7\%) strongly agreed. The findings obtained show that the majority of the respondents agreed that verbal and written feedback from the supervisors was being done (Mean $=4.063, \mathrm{SD}=1.199$ ). This finding implies that besides issuing written feedback may through minutes the supervisors probably gave follow-up explanations verbally.

This may have been for purposes of cementing whatever was written down. These findings are consistent with Donalson and Donalson's (2012) report that teachers need constructive feedback from skilled practitioners in order to improve their teaching. As compared to the current study the feedback can be said to be either verbal or written. Opposing these views however is Zatynski's (2012) assertions that feedback is often not a common occurrence in schools. This, therefore, means that there is no frequent, active teacher involvement on performance appraisal, an area that this study is also interested in establishing.

Findings in Table 2 indicated that 42 (14\%) of the respondents strongly disagreed that supervisors hold a performance review meeting to discuss performance outcome, 15 (5\%) disagreed, 124 (41.3\%) agreed while 98 (32.7\%) strongly agreed. The findings obtained show that the majority of the respondents agreed that supervisors hold a performance review meeting to discuss performance outcomes (Mean =3.737, SD = 1.339). Lastly, findings in Table 2 indicated that 33 (11\%) of the respondents strongly disagreed that they are provided with feedback based on factual evidence on my performance, 41 (13.7\%) disagreed, 113 (37.7\%) agreed while 106 (35.3\%) strongly agreed. The findings obtained show that the majority of the respondents agreed that supervisors provide feedback that was factual (Mean $=3$.provide727, $\mathrm{SD}=1.358$ ). This implies that teachers were implementing the TPAD policy by providing verifiable evidences such as log in and log out data, community participation, and lesson attendance data among others. Wango's (2010) findings are consistent with the current study which indicated that, during performance appraisal feedback, the appraisers must be clear in explaining their judgments concerning the strengths and weaknesses so that teachers identify how to improve their work.

\subsection{Reward System}

The respondents were asked to rate on the reward system in the implementation of TPAD. The findings are indicated in Table 3. Findings indicated that $23(7.7 \%)$ of the respondents strongly disagreed that teachers' work contribution is recognized by the supervisor, 37 (12.3\%) disagreed, 114 (38\%) agreed while 106 (35.37\%) strongly agreed. The findings obtained show that majority of the respondents agreed that teacher work contribution is recognized by the supervisor (Mean $=3.81, \mathrm{SD}=1.254$ ). Besides the 
challenges and the gaps that teachers might have raised were being addressed accordingly.

Findings in Table 3 indicated that 120 (40\%) of the respondents strongly disagreed that TSC provides teachers with an opportunity for career advancement, 101 (33.7\%) disagreed, 39 (13\%) agreed while $37(12.3 \%)$ strongly agreed. The findings obtained show that the majority of the respondents disagreed that TSC provides teachers with opportunities for career advancement (Mean $=2.240, \mathrm{SD}=1.410)$. This finding implies that the appraisees were not undertaking career progression because TSC was not providing that opportunity.

Most importantly however is to underscore that the career progression guidelines are well established within the TSC. Apparently, teachers are supposed to sponsor themselves for these career advancements. Financial constraints may have limited teachers' participation in career advancement. Providing employees with training and developmental opportunities encourage good performance, strengthens, job-related skills and competencies, and helps employees keep up with changes in the workplace such as the introduction of new technology or methods (Michael, 2006). It is therefore imperative that opportunities are created for teachers to explore the gaps that were identified.

Table 3: Reward System

\begin{tabular}{|c|c|c|c|c|c|c|c|}
\hline Reward system & SD & D & $\mathbf{N}$ & A & SA & Mean & $\begin{array}{l}\text { Std. } \\
\text { Dev. }\end{array}$ \\
\hline $\begin{array}{l}\text { a. Teacher work contribution } \\
\text { is recognized by the } \\
\text { supervisor }\end{array}$ & $\begin{array}{c}23 \\
(7.7 \%)\end{array}$ & $\begin{array}{c}37 \\
(12.3 \%)\end{array}$ & $\begin{array}{c}20 \\
(114 \%)\end{array}$ & $\begin{array}{c}114 \\
(38 \%)\end{array}$ & $\begin{array}{c}106 \\
(35.3 \%)\end{array}$ & 3.810 & 1.254 \\
\hline $\begin{array}{ll}\text { b. } & \text { TSC provides teachers } \\
\text { with opportunity for career } \\
\text { advancement }\end{array}$ & $\begin{array}{c}120 \\
(40 \%)\end{array}$ & $\begin{array}{c}101 \\
(33.7 \%)\end{array}$ & $\begin{array}{c}3 \\
(1 \%)\end{array}$ & $\begin{array}{c}39 \\
(13 \%)\end{array}$ & $\begin{array}{c}37 \\
(12.3 \%)\end{array}$ & 2.240 & 1.410 \\
\hline $\begin{array}{ll}\text { c. } & \text { TSC links work } \\
& \text { performance with rewards }\end{array}$ & $\begin{array}{c}22 \\
(7.3 \%) \\
\end{array}$ & $\begin{array}{c}39 \\
(13 \%) \\
\end{array}$ & $\begin{array}{c}10 \\
(3.3 \%) \\
\end{array}$ & $\begin{array}{c}98 \\
(32.7 \%) \\
\end{array}$ & $\begin{array}{c}131 \\
(43.7 \%) \\
\end{array}$ & 3.923 & 1.284 \\
\hline $\begin{array}{l}\text { d. TSC pegs promotions on } \\
\text { work performance }\end{array}$ & $\begin{array}{c}25 \\
(8.3 \%) \\
\end{array}$ & $\begin{array}{c}49 \\
(16.3 \%) \\
\end{array}$ & $\begin{array}{c}11 \\
(3.7 \%) \\
\end{array}$ & $\begin{array}{c}113 \\
(37.7 \%) \\
\end{array}$ & $\begin{array}{c}102 \\
(34 \%) \\
\end{array}$ & 3.727 & 1.308 \\
\hline $\begin{array}{l}\text { e. A report on the learner's } \\
\text { achievement is discussed } \\
\text { with a view to improve } \\
\text { performance } \\
\end{array}$ & $\begin{array}{c}17 \\
(5.75 \%)\end{array}$ & $\begin{array}{c}15 \\
(5 \%)\end{array}$ & $\begin{array}{c}16 \\
(5.3 \%)\end{array}$ & $\begin{array}{c}154 \\
(51.3 \%)\end{array}$ & $\begin{array}{c}98 \\
(32.7 \%)\end{array}$ & 4.003 & 1.046 \\
\hline 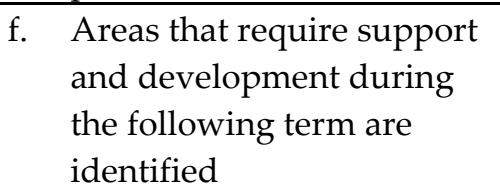 & $\begin{array}{c}42 \\
(14 \%)\end{array}$ & $\begin{array}{c}33 \\
(11 \%)\end{array}$ & $\begin{array}{c}13 \\
(4.3 \%)\end{array}$ & $\begin{array}{c}111 \\
(37 \%)\end{array}$ & $\begin{array}{c}101 \\
(33.7 \%)\end{array}$ & 3.653 & 1.402 \\
\hline $\begin{array}{ll}\text { g. } & \begin{array}{l}\text { Training plan on identified } \\
\text { gaps is generated after } \\
\text { needs assessment }\end{array} \\
\end{array}$ & $\begin{array}{c}150 \\
(50 \%)\end{array}$ & $\begin{array}{c}100 \\
(33.3 \%)\end{array}$ & $\begin{array}{c}8 \\
(2.7 \%)\end{array}$ & $\begin{array}{c}15 \\
(5 \%)\end{array}$ & $\begin{array}{c}27 \\
(9 \%)\end{array}$ & 1.93 & 1.254 \\
\hline
\end{tabular}

Findings in Table 3 indicated that $22(7.3 \%)$ of the respondents strongly disagreed that TSC links work performance with rewards, 39 (13\%) disagreed, 98 (32.7\%) agreed while 
$131(43.7 \%)$ strongly agreed. The findings obtained show that the majority of the respondents agreed that TSC links work performance with rewards (Mean $=3.923, \mathrm{SD}=$ 1.284). The TSC has been categorical in pegging job grade promotion to the teachers' performance. The TPAD tool is one of the key components during the processes of promotion. Therefore, by teachers agreeing to the fact that TSC links work performance with rewards, it leaves no doubts to that. This is in line with the assertion that the introduction of Teacher Performance Appraisals as an evaluation has been perceived as a means of managing teachers, motivating them (AEU, 2013).

Findings in Table 3 indicated that $25(8.3 \%)$ of the respondents strongly disagreed that TSC pegs promotions on work performance, 49 (16.3\%) disagreed, 113 (37.7\%) agreed while $102(34 \%)$ strongly agreed. The findings obtained show that majority of the respondents agreed that TSC pegs promotions on work performance (Mean $=3.727, \mathrm{SD}=$ 1.308). This finding implies that for teachers to be promoted from one job grade to the other their work performance in terms of learners' gradual progress and time management has to be positive.

By teachers acknowledging that TSC promotes alongside performance, it implies that the implementation process is on point. Contrary to the opinions of the majority of respondents regarding promotion and work performance, Akampurira (2010), opines that heads of institutions and teachers have complained of the efficiency of performance evaluation. In some cases, some teachers have been promoted without linking the promotion on performance appraisal reports hence raising more doubt on the effectiveness of Teachers' performance appraisal reports. In worse circumstances, it is where performing teachers have been left out while promotions are done. Most important conditions of performance appraisal such as linking performance with rewards have been ignored.

Findings in Table 3 indicated that 17 (5.7\%) of the respondents strongly disagreed that a report on the learner's achievement is discussed with a view to improving performance, 15 (5\%) disagreed, 154 (51.3\%) agreed while 98 (32.7\%) strongly agreed. The findings obtained show that the majority of the respondents agreed that a report on the learners' achievement is discussed with a view to improving performance (Mean $=4.003$, $\mathrm{SD}=1.046$ ). This finding implies that when results such as KCSE are released learners' individual performance is discussed at the school level with the intent of improving subsequent performances. Internal mechanisms are also put in place upon the release of continuous assessments tests with the main aim of improving performance. This is done during staff briefs and also board meetings.

Findings in Table 3 indicated that 42 (147\%) of the respondents strongly disagreed that areas that require support and development during the following term are identified, 33 (11\%) disagreed, 111 (\%37) agreed while 101 (33.7\%) strongly agreed. The findings obtained show that the majority of the respondents agreed that areas that require support and development during the following term are identified (Mean = 3.653, SD = 1.402). This finding implies that as part of the implementation process the TPAD espouses on the areas that were a challenge to teachers and how these areas should be rectified or 
improved. This implies that the school will provide the necessary facilities to improve those areas of weakness.

Findings in Table 3 indicated that 150 (50\%) of the respondents strongly disagreed that a training plan on identified gaps is generated after a needs assessment, $100(33.3 \%)$ disagreed, $15(5 \%)$ agreed while 27 (9\%) strongly agreed. The findings obtained show that the majority of the respondents disagreed that a training plan on identified gaps is generated after needs assessment $(\mathrm{Mean}=1.93, \mathrm{SD}=1.402)$. This finding implies that schools or teachers may not be having adequate funding that will enable training of teachers as much as the gaps have been identified in the need's assessment. This finding is in line with a study by Hamis (2010) on the Effect of Performance Appraisal Result on Personnel Motivation and Job Promotion. The study concluded that teacher appraisal is an important function in identifying the people's talents and capacities and its results can make them aware of advancements, plans, and goals.

\subsection{Management of ICT Infrastructural Resources}

The respondents were asked to rate on a five-point Likert scale their level of agreement on several statements describing the management of ICT infrastructural resources in Public Secondary schools in Trans Nzoia County and their responses were summarized in Table 4.

Findings in Table 4 further indicated that 92 (30.7\%) of the respondents strongly disagreed that there has been improved ICT infrastructure in the school, 88 (29.3\%) disagreed, 54 (18\%) agreed while $65(21.7 \%)$ strongly agreed. The findings obtained show that majority of the respondents disagreed that ICT infrastructure has improved in school (Mean $=2.7067, \mathrm{SD}=1.577$ ). In a related study, Makhanu (2010) undertook an exploratory study on "Principals' literacy in ICT: towards improving secondary school performance in Kenya". It was found that there was a statistically significant and positive though weak relationship between the ability of a principal to use the internet or email and school performance.

Given that the effect size was very small, it implied that the ability of a principal to use the internet or email plays a negligible role in influencing the school performance. The study concluded that there is a positive correlation between the ICT literacy level of a principal and secondary school performance in the Western province of Kenya. Though Makhanu's study pinpoints the weak association between ICT and school performance, the current study pinpoints that ICT infrastructure was inadequately developed, implying that even the Principals or teachers may not be in a position to utilize the resource such as sending emails.

Findings indicated that $141(47 \%)$ of the respondents strongly disagreed that the school is networked, 39 (13\%) disagreed, 64 (21.3\%) agreed while 43 (14.3\%) strongly agreed. The findings obtained show that the majority of the respondents disagreed that the school is networked (Mean $=2.43, \mathrm{SD}=1.574)$. Findings indicated that $85(28.3 \%)$ of the respondents strongly disagreed that ICT facilities such as projectors, 99 (33\%) disagreed, 53 (17.7\%) agreed while 45 (15\%) strongly agreed. The findings obtained show 
that majority of the respondents disagreed that the ICT facilities such as projectors laptops have been connected $($ Mean $=2.58, \mathrm{SD}=1.4389)$.

Table 4: Effects of Management of ICT Infrastructural Resources on Implementation of TPAD policy in Public Secondary Schools in Trans Nzoia County

\begin{tabular}{|c|c|c|c|c|c|c|c|}
\hline & SD & $\mathrm{D}$ & $\mathbf{N}$ & A & SA & Mean & SD \\
\hline $\begin{array}{l}\text { a. There has been improved ICT } \\
\text { infrastructure in school }\end{array}$ & $\begin{array}{c}92 \\
(30.7 \%) \\
\end{array}$ & $\begin{array}{c}88 \\
(29.3 \%) \\
\end{array}$ & $\begin{array}{c}1 \\
(0.3 \%) \\
\end{array}$ & $\begin{array}{r}54 \\
(185) \\
\end{array}$ & $\begin{array}{c}65 \\
(21.7 \%) \\
\end{array}$ & 2.7067 & 1.57763 \\
\hline b. The school is networked & $\begin{array}{c}141 \\
(47 \%) \\
\end{array}$ & $\begin{array}{c}39 \\
(13 \%) \\
\end{array}$ & $\begin{array}{c}13 \\
(4.3 \%) \\
\end{array}$ & $\begin{array}{c}64 \\
(21.3 \%) \\
\end{array}$ & $\begin{array}{c}43 \\
(14.3 \%) \\
\end{array}$ & 2.4300 & 1.57481 \\
\hline $\begin{array}{l}\text { c. ICT facilities such as projectors } \\
\text { laptops have been connected }\end{array}$ & $\begin{array}{c}85 \\
(28.3 \%) \\
\end{array}$ & $\begin{array}{c}99 \\
(33 \%) \\
\end{array}$ & $\begin{array}{c}18 \\
(6 \%) \\
\end{array}$ & $\begin{array}{c}53 \\
(17.7 \%) \\
\end{array}$ & $\begin{array}{c}45 \\
(15 \%) \\
\end{array}$ & 2.5800 & 1.43892 \\
\hline $\begin{array}{l}\text { d. ICT is used to access online } \\
\text { educational resources }\end{array}$ & $\begin{array}{c}98 \\
(32.7 \%) \\
\end{array}$ & $\begin{array}{c}57 \\
(19 \%) \\
\end{array}$ & $\begin{array}{c}43 \\
(14.3 \%) \\
\end{array}$ & $\begin{array}{c}52 \\
(17.3 \%) \\
\end{array}$ & $\begin{array}{c}50 \\
(16.7 \%) \\
\end{array}$ & 2.6633 & 1.49357 \\
\hline $\begin{array}{l}\text { e. The school is connected at least } \\
\text { at a basic level, that is having a } \\
\text { website email for students and } \\
\text { teachers, a local area network } \\
\text { or a virtual learning } \\
\text { environment }\end{array}$ & $\begin{array}{c}180 \\
(60 \%)\end{array}$ & $\begin{array}{c}30 \\
(10 \%)\end{array}$ & $\begin{array}{c}12 \\
(4 \%)\end{array}$ & $\begin{array}{c}36 \\
(12 \%)\end{array}$ & $\begin{array}{c}42 \\
(14 \%)\end{array}$ & 2.1000 & 1.54205 \\
\hline $\begin{array}{ll}\text { f. } & \text { There are sufficient ICT } \\
\text { materials }\end{array}$ & $\begin{array}{c}145 \\
(48.3 \%) \\
\end{array}$ & $\begin{array}{c}28 \\
(9.3 \%) \\
\end{array}$ & $\begin{array}{c}28 \\
(9.3 \%) \\
\end{array}$ & $\begin{array}{c}72 \\
(24 \%) \\
\end{array}$ & $\begin{array}{c}27 \\
(9 \%) \\
\end{array}$ & 2.3600 & 1.49147 \\
\hline $\begin{array}{l}\text { g. High levels of virtual learning } \\
\text { environment provision can be } \\
\text { seen }\end{array}$ & $\begin{array}{c}246 \\
(82 \%)\end{array}$ & $\begin{array}{c}6 \\
(2 \%)\end{array}$ & $\begin{array}{c}11 \\
(3.7 \%)\end{array}$ & $\begin{array}{c}22 \\
(7.3 \%)\end{array}$ & $\begin{array}{c}15 \\
(5 \%)\end{array}$ & 1.5133 & 1.16949 \\
\hline $\begin{array}{l}\text { h. There is an ICT technician who } \\
\text { assist in maintaining ICT } \\
\text { equipment in schools }\end{array}$ & $\begin{array}{c}240 \\
(80 \%)\end{array}$ & $\begin{array}{c}23 \\
(7.7 \%)\end{array}$ & $\begin{array}{c}12 \\
(4 \%)\end{array}$ & $\begin{array}{c}15 \\
(5 \%)\end{array}$ & $\begin{array}{c}10 \\
(3.3 \%)\end{array}$ & 1.4400 & 1.01481 \\
\hline $\begin{array}{l}\text { i. There are on average over } 100 \\
\text { students per interactive } \\
\text { whiteboard and } 50 \text { per data } \\
\text { projector }\end{array}$ & $\begin{array}{c}245 \\
(81.7 \%\end{array}$ & $\begin{array}{c}22 \\
(7.3 \%)\end{array}$ & $\begin{array}{c}17 \\
(5.7 \%)\end{array}$ & $\begin{array}{c}5 \\
(1.7 \%)\end{array}$ & $\begin{array}{c}11 \\
(3.7 \%)\end{array}$ & 1.3833 & .94483 \\
\hline $\begin{array}{l}\text { j. } \\
\text { Access to an education site or } \\
\text { network maintained by } \\
\text { education authorities }\end{array}$ & $\begin{array}{c}240 \\
(80 \%)\end{array}$ & $\begin{array}{c}34 \\
(11.3 \%)\end{array}$ & $\begin{array}{c}0 \\
(0 \%)\end{array}$ & $\begin{array}{c}11 \\
(3.7 \%)\end{array}$ & $\begin{array}{c}15 \\
(5 \%)\end{array}$ & 1.4233 & 1.03329 \\
\hline
\end{tabular}

Findings further indicated that 98 (32.7\%) of the respondents strongly disagreed that ICT is used to access online educational resources, $57(19 \%)$ disagreed, $52(17.3 \%)$ agreed while $50(16.7 \%)$ strongly agreed. The findings obtained show that majority of the respondents disagreed that the ICT is used to access online educational resources (Mean $=2.663, \mathrm{SD}=1.4935)$. Findings indicated that $180(60 \%)$ of the respondents strongly disagreed that their school is connected at least at a basic level, that is having a website email for students and teachers, a local area network, or a virtual learning environment, $30(10 \%)$ disagreed, $36(12 \%)$ agreed while 42 (14\%) strongly agreed. The findings obtained show that the majority of the respondents disagreed that the ICT is used to access online educational resources (Mean $=2.1, \mathrm{SD}=1.5420$ ). 
Findings further indicated that 145 (48.3\%) of the respondents strongly disagreed that there are sufficient ICT materials, 28 (9.3\%) disagreed, $72(24 \%)$ agreed while 27(9\%) strongly agreed. The findings obtained show that majority of the respondents disagreed that there are sufficient ICT materials (Mean $=2.36, \mathrm{SD}=1.4914$ ). Findings indicated that $246(82 \%)$ of the respondents strongly disagreed that there are high levels of virtual learning environment provision, 6 (2\%) disagreed, 22 (7.3\%) agreed while 15 (5\%) strongly agreed. The findings obtained show that the majority of the respondents disagreed that there are high levels of the virtual learning environment (Mean $=1.5133$, $\mathrm{SD}=1.1694)$.

Findings indicated that $240(80 \%)$ of the respondents strongly disagreed that there is an ICT technician who assists in maintaining ICT equipment in schools, 23 (7.7\%) disagreed, 15 (5\%) agreed while 10 (3.3\%) strongly agreed. The findings obtained show that majority of the respondents disagreed that there is an ICT technician who assists in maintaining ICT equipment in schools (Mean $=1.44, \mathrm{SD}=1.014$ ). Findings further indicated that $245(81.7 \%)$ of the respondents strongly disagreed that there are on average over 100 students per interactive whiteboard and 50 per data projector, 22 (7.3\%) disagreed, $5(1.7 \%)$ agreed while $11(3.7 \%)$ strongly agreed. The findings obtained show that majority of the respondents disagreed that there are on average over 100 students per interactive whiteboard and 50 per data projector there is an ICT technician who assists in maintaining ICT equipment in schools (Mean $=1.3833, \mathrm{SD}=0.9448$ ).

Lastly, findings in Table 4 further indicated that $240(80 \%)$ of the respondents strongly disagreed that there is access to an education site or network maintained by education authorities, $34(11.3 \%)$ disagreed, 11 (3.7\%) agreed while 15 (5\%) strongly agreed. The findings obtained show that majority of the respondents disagreed that there is access to an education site or network maintained by education authorities (Mean = $1.4233, \mathrm{SD}=1.033)$.

Ho3: Management of ICT Infrastructure resources has no significant effect on the implementation of TPAD policy in public secondary schools in Trans Nzoia.

A linear regression model was used to explore the effect of ICT infrastructure resources on the implementation of TPAD policy. From the model, $\left(\mathrm{R}^{2}=.206\right.$ shows that ICT infrastructure resources account for $20.6 \%$ variation in the implementation of TPAD policy. The $\mathrm{R}^{2}$ represented the measure of variability in the implementation of TPAD policy that ICT infrastructure resources accounted for. The ICT infrastructure resource predictor used in the model captured the variation in the implementation of TPAD policy as shown in Table 5. The adjusted R square of .203 depicts that the ICT infrastructure resource in exclusion of the constant variable explained the variation in the implementation of TPAD policy by $20.3 \%$ the remaining percentage can be explained by other factors excluded from the model. 
Table 5: Model Summary on ICT Infrastructure and Implementation of TPAD Policy

\begin{tabular}{|c|c|c|c|c|}
\hline Model & R & R Square & Adjusted R Square & Std. Error of the Estimate \\
\hline 1 & $.454^{\mathrm{a}}$ & .206 & .203 & 10.10302 \\
\hline
\end{tabular}

a. Predictors: (Constant), ICT resources

The analysis of variance was used to test whether the model could significantly fit in predicting the outcome than using the mean as shown in (Table 6). The regression model with ICT infrastructure resource as a predictor was significant $(\mathrm{F}=77.444$, $\mathrm{p}$ value $=0.001)$ shows that there is a significant relationship between ICT infrastructure and implementation of TPAD policy.

Table 8: Analysis of Variance on Infrastructure and Implementation of TPAD Policy

\begin{tabular}{|l|l|c|c|c|c|c|}
\hline \multicolumn{2}{|l|}{ Model } & Sum of Squares & df & Mean Square & F & Sig. \\
\hline \multirow{2}{*}{1} & Regression & 7894.600 & 1 & 7894.600 & \multirow{2}{*}{77.344} & \multirow{2}{*}{$.000^{\mathrm{b}}$} \\
\cline { 2 - 5 } & Residual & 30417.170 & 298 & 102.071 & & \\
\cline { 2 - 7 } & Total & 38311.770 & 299 & & & \\
\hline
\end{tabular}

a. Dependent Variable: Implementation of TPAD policy

b. Predictors: (Constant), ICT resources

In addition, the $\beta$ coefficients for ICT infrastructure resource as an independent variable were generated from the model, in order to test the hypotheses under study. The t-test was used as a measure to identify whether the ICT infrastructure resource as a predictor is making a significant contribution to the model. Table 7 shows the estimates of $\beta$-value and gives the contribution of the predictor to the model. The $\beta$-value for ICT infrastructure resource had a positive coefficient, depicting a positive relationship with implementation of TPAD policy as summarized in the model as:

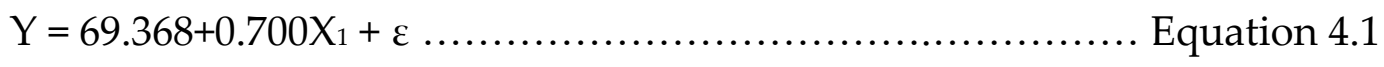

Where:

$\mathrm{Y}=$ Implementation of TPAD policy,

$\mathrm{X}_{1}=\mathrm{ICT}$ infrastructure resource,

$\varepsilon=$ error term

From the findings the t-test associated with $\beta$-values was significant and the ICT infrastructure resource as the predictor was making a significant contribution to the model. The coefficients result in Table 7 showed that the predicted parameter in relation to the independent factor was significant; $\beta_{1}=0.700(\mathrm{P}<0.05)$. 
Table 7: Management of ICT Infrastructure and Implementation of TPAD Policy Coefficients

\begin{tabular}{|c|c|c|c|c|c|c|}
\hline \multirow{2}{*}{\multicolumn{2}{|c|}{ Model }} & \multicolumn{2}{|c|}{ Unstandardized Coefficients } & \multirow{2}{*}{$\frac{\text { Standardized Coefficients }}{\text { Beta }}$} & \multirow[b]{2}{*}{$\mathbf{t}$} & \multirow{2}{*}{ Sig. } \\
\hline & & B & Std. Error & & & \\
\hline \multirow{2}{*}{1} & (Constant) & 69.368 & 1.740 & & 39.856 & .000 \\
\hline & ICT resources & .700 & .080 & .454 & 8.795 & .000 \\
\hline
\end{tabular}

a. Dependent Variable: Implementation of TPAD policy

The study hypothesized that there is no significant effect of ICT infrastructure resources on the implementation of TPAD policy. The study findings depicted that there was a positive significant effect of ICT infrastructure resource on implementation of TPAD policy $\left(\beta_{3}=0.700\right.$ and $p$ value $\left.<0.05\right)$. Therefore, an increase in ICT infrastructure resources leads to an increase in the implementation of the TPAD policy. The null hypothesis ( $\mathrm{Ho} 1)$ was rejected. Therefore, ICT infrastructure resources had a significant influence on the implementation of TPAD policy. This implies that for each increase in the ICT infrastructure resource, there was more implementation of the TPAD policy.

\section{Conclusions}

The study concluded that the management of ICT infrastructural resources was critical to the implementation of TPAD in public secondary schools in Trans Nzoia County. ICT resources basically provided an enabling environment necessary for operating TPAD online system.

The study concluded that the management of teaching staff affects the implementation of TPAD in public secondary schools in Trans Nzoia County. Head teachers with better staff management skills helped teachers to shift to the new paradigm of an appraisal system which has openness, reliability, and accountability as its hallmarks.

\subsection{Recommendations}

The Ministry of Education and TSC should improve ICT infrastructure especially in subcounty schools and continuously capacity build teachers and school administrators on emerging trends in education management information systems. There is a need for the ministry of education to provide ICT infrastructural resources in every public secondary school in Trans Nzoia County in order to enhance the implementation of the TPAD policy.

Since the study was conducted in one out of the existing 47 counties of Kenya, the study could be replicated in all the other 46 counties to have a broader picture. Such a study would help stakeholders in education to know the concerns of teachers in the entire country to inform policy and practice. A similar study can also be carried out in the other levels of education such as the pre-primary primary and tertiary institutions to ascertain the effects of TPAD implementation on the management of these institutions. 


\section{Conflict of Interest Statement}

The authors declare no conflicts of interest.

\section{About the Authors}

Benson Chege Njuguna is a PhD student at Department of Educational Management University of Eldoret, Kenya.

Dr. Lydia Kipkoech is a lecturer at the Department of Educational Management, School of Education, University of Eldoret, Kenya.

Dr. Simon Wanami is a Senior Lecturer, Department of Technology Education at University of Eldoret, Kenya.

\section{References}

Ademola, S. (2017). Impact of performance appraisal on employee performance. International journal of economics and business management vol.3 (1) 80-90.

Australian Education Union (AEU) (2013). Beginning teachers' list workload, behaviour management, pay and class size as top concerns. Melbourne: AEU. Retrieved from http://www.aeufederal. org.au/Media/ Media Releases/2013/0202.pdf

Ahmed, H. M. S. (2016). Technology in Performance Appraisal System with Specific Reference to Group of Companies HSA and its Partners in the Republic of Yemen. IBMRD's Journal of Management $\mathcal{E}$ Research, 5(1), 1-6.

Akampurira, A. (2010). The effect of teachers performance appraisal in secondary schools. Unpublished dissertation, Grin Verlag.

Allen, C., Hadjistassou, S. K., \& Richardson, D. (2016). Self-evaluation using iPads in EFL teaching practice. CALL communities and culture-short papers from EUROCALL, 2024 Alubbe (2015)

Bayon, S. (2013). The origin, concept and value of performance appraisal. International journal economics, commerce and management vol1 (2) 1-17.

Boko, J. M., Danku, S. W., Dordor, F. \& Soglo, N. Y. (2015). performance appraisal in the Ghana Education servicer. International journal of managerial studies and research 3 (6) 117-133

Bolona Lopez, M., Ortiz, M., \& Allen, C. (2015). Using mobile devices and the AdobeConnect web conferencing tool in the assessment of EFL student teacher performance. In F. Helm, L. Bradley, M. Guarda, \& S. Thouësny (Eds), Critical CALL - Proceedings of the 2015 EUROCALL Conference, Padova, Italy (pp. 77-83). Dublin Ireland: Researchublishing.net https://doi.org/10.14705/rpnet.2015.000313

Brown, M., Kulik, C. T., \& Lim, V. (2016). Managerial tactics for communicating negative performance feedback. Personnel Review.

Creswell, J. W. (2013). Steps in Conducting a Scholarly Mixed Methods Study. DBER Speaker Series. Paper 48. http://digitalcommons.unl.edu/dberspeakers/48

Darling - Hammond (2013). Evaluating Teacher Evaluation. Colleagues, 10 (2), article 8. 
Donalson and Donalson (2012). England National Statistics. (2011). Statistics of education: Survey of information and communication in schools from 2001. Retrieved September 12 , 2014 from http://webarchive.nationalarchives.gov.uk/20130401151655/http://media.educatio n.gov.uk/assets/files/pdf/b092001pdf.pdf

Hamis, M. (2010). Knowledge, attitude and practice towards HIV/AIDS among barabaig pastoralists of Hanang and Babati districts-Tanzania (Doctoral dissertation, Sokoine University of Agriculture).

Hellrung, K., \& Hartig, J. (2013). Understanding and using feedback-A review of empirical studies concerning feedback from external evaluations to teachers. Educational Research Review, 9, 174-190.

Higgins, T. E., \& McCann, D. C. (1984). Social encoding and subsequent attitudes, impressions, and memory: "Context-driven" and motivational aspects of processing". Journal of Personality and Social Psychology, p47.

Jonyo, D. O., \& Jonyo, B. O. (2017). Performance Management in Kenyan Public Schools: Implications and challenges. European Journal of Educational Sciences EJES, 19-35

Kamener, L. (2012). Delivering Real Change in the Approach to Performance and Development in Schools, Melbourne, and Vic. Boston Consulting group. Kamuri C.P. (2012 May 25). Teachers should not Reject Performance Contracts. The Standard News Paper, Kenya (P.46).

Kamiti, R. K. (2014). The effect of performance appraisal system on civil servants motivation. Unpublished dissertation, University of Nairobi.

Kamuri C. P. (2012 May 25). Teachers should not Reject Performance Contracts. The Standard News Paper, Kenya (P.46).

Kanisa, N. O. \& Makokha, E. N. (2017). Effect of performance appraisal on organizational performances. European Journal of Business and management, 9 (26) 95-101.

Karyeija, G. K. (2012). The impact of culture on Performance Appraisal Reforms in Africa: The case of Uganda's Civil Service. Asian Social Science, 8(4) 159- 174.

Kelly, K. O., Ang, S. Y. A., Chong, W. L., \& Hu, W. S. (2008). Teacher appraisal and its outcomes in Singapore primary schools. Journal of Educational Administration.

Kukulska-Hulme A. (2012). How should the higher education workforce adapt to advancements in technology for teaching and learning?. The Internet and Higher Education, 15(4), 247-254.

Leask, M., \& Pachler, M. (Eds). (2013). Learning to teach in the secondary schools: A comparison of school experience (3rd Ed.). New York: Routledge.

Locke, E. A., \& Latham, G. P. (2002). Building a practically useful theory of goal setting and task motivation: A 35-year odyssey. American psychologist, 57(9), 705.

Latham, G. P., \& Locke, E. A. (2007). New developments in and directions for goal-setting research. European Psychologist, 12(4), 290-300.

Locke, E. A. (1968). Effects of knowledge of results, feedback in relation to standards, and goals on reaction-time performance. The American Journal of Psychology, 81(4), 566574 . 
Makhanu, E. S. (2010). Principals' literacy in ICT: towards improving secondary school performance in Kenya. PhD thesis. Pretoria: University of South Africa.

Mbatha, M. F. (2017). An analysis of educators' perceptions of the developmental appraisal system: a case study of schools in Richards Bay (Doctoral dissertation).

Boit, M. J., \& Menjo, K. D. (2012). The challenges of using information communication technology (ICT) in school administration in Kenya. Journal of Emerging Trends in Educational Research and Policy Studies, 55-60.

Mertens, D. M. (2007). Transformative paradigm: Mixed methods and social justice. Journal of mixed methods research, 1(3), 212-225.

Michael, F. (2006). Performance and performance standards Opinion. NSPI journal

Morgan, D. L. (2007). Paradigms lost and pragmatism regained: Methodological implications of combining qualitative and quantitative methods. Journal of mixed methods research, 1(1), 48-76.

Odhiambo, E. (2015). The role of performance management practices on employee productivity. Unpublished MBA dissertation, United States International University.

Offevenger, W., van der Akker, J. J. H., \& Fater, L. (2007). Developing sciences, mathematics and ICT education in Sub-Saharan Africa: patters and promising practices. Washington DC: The World Bank.

Ombui, S. C. (2013). The challenges facing principals in integrating ICT for efficient management in secondary schools was carried out in Nyamira County. Unpublished masters' thesis, Kenya University, Nairobi, Kenya. Unpublished MBA, Dissertation University of Nairobi.

Oyaro, C. (2016). Factors Influencing Teachers' Attitudes towards Performance Appraisal in Public Secondary Schools in Imenti North Sub County, Kenya (Doctoral dissertation, University of Nairobi).

Salaman, G., Storey, J., \& Billsberry, J. (2005). Strategic Human Resource Management: Theory and Practice. 2nd Edition. Sage Publications Ltd.

Stronge, J. H., \& Tucker, P. D. (2003). Handbook on teacher evaluation: Assessing and improving performance. New York: Eye on Education.

Surbhi, S. (2015). Difference between performance appraisal and performance management. $\quad$ http://keydifferences.com/difference-between-performanceappraisal-and-performance-management.html\#ixzz4T0hmbbQh. Accessed on $16 / 12 / 2016$

Timperley H. S. (2011b). Knowledge and The Leadership of Learning- Leadership and Policy in Schools,10, 1-26- A journal on "Building professional capability in schooling improvement."

Tmison, T., \& Taylor, P. H. (2001). Managing ICT in secondary schools. Oxford: Heinemann Educational Publishers.

Tshabalala, T. \& Mapolisa, T. (2013). Problems Faced by Heads of Schools and Teachers in the Implementation of Performance Appraisal in Zimbabwe: Perceptions of Heads of Heads of Schools and Teachers in Nkayi District, Zimbabwe. International Journal of Advanced Research, 1, (8), 750-758 
Wango G. (2010). School Administration and Management. Quality Assurance and standard schools. Jomo Kenyatta Foundation. Nairobi Kenya

Yamane, T. (1967). Statistics: An introductory analysis, 2nd Ed., New York: Harper and Row.

Zatynski, M. (2012). Revamping Teacher Evaluation. Principal, 91(5), 22-27. 
Creative Commons licensing terms

Author(s) will retain the copyright of their published articles agreeing that a Creative Commons Attribution 4.0 International License (CC BY 4.0) terms will be applied to their work. Under the terms of this license, no permission is required from the author(s) or publisher for members of the community to copy, distribute, transmit or adapt the article content, providing a proper, prominent and unambiguous attribution to the authors in a manner that makes clear that the materials are being reused under permission of a Creative Commons License. Views, opinions and conclusions expressed in this research article are views, opinions and conclusions of the author(s). Open Access Publishing Group and European Journal of Education Studies shall not be responsible or answerable for any loss, damage or liability caused in relation to/arising out of conflicts of interest, copyright violations and inappropriate or inaccurate use of any kind content related or integrated into the research work. All the published works are meeting the Open Access Publishing requirements and can be freely accessed, shared, modified, distributed and used in educational, commercial and non-commercial purposes under a Creative Commons Attribution 4.0 International License (CC BY 4.0). 